\title{
Elemental concentration and migratability in bioplastics derived from organic waste
}

\author{
Maria Luisa Astolfi ${ }^{\text {a, }}{ }^{*}$, Elisabetta Marconi ${ }^{b}$, Laura Lorini ${ }^{a}$, Francesco Valentino ${ }^{a}$, \\ Fernando Silva ${ }^{c}$, Bruno Sommer Ferreira ${ }^{d}$, Silvia Canepari ${ }^{a}$, Mauro Majone ${ }^{a}$ \\ a Department of Chemistry, Sapienza University, Piazzale Aldo Moro 5, 00185, Rome, Italy \\ ${ }^{\mathrm{b}}$ Department of Public Health and Infectious Diseases, Sapienza University, Piazzale Aldo Moro 5, 00185, Rome, Italy \\ c Department of Chemistry, Faculdade de Ciências e Tecnologia, Universidade Nova de Lisboa, 2829-516, Caparica, Portugal \\ ${ }^{\mathrm{d}}$ Biotrend - Inovacão e Engenharia em Biotecnologia, S.A., Biocant Park, Núcleo 04 Lote 2, 3060-197, Cantanhede, Portugal
}

\section{H I G H L I G H T S}

- Elemental composition of a new PHA derived from organic waste is reported.

- Feedstock type and production process affect the element levels of PHA.

- Migratability is evaluated using different solutions and conditions.

- Migratability increases under simulated acidic conditions and with heating.

- Possible use of PHA was evaluated by comparison with regulations and guidelines.

\section{A R T I C L E I N F O}

\section{Article history:}

Received 8 April 2020

Received in revised form 8 June 2020

Accepted 16 June 2020

Available online 22 June 2020

Handling Editor: Grzegorz Lisak

\section{Keywords:}

Biopolymers

Polyhydroxyalkanoates

Bioaccessibility

Toxic elements

Inductively coupled plasma mass

spectrometry

Cold vapour generation atomic fluorescence spectrometry
G R A P H I C A L A B S T R A C T

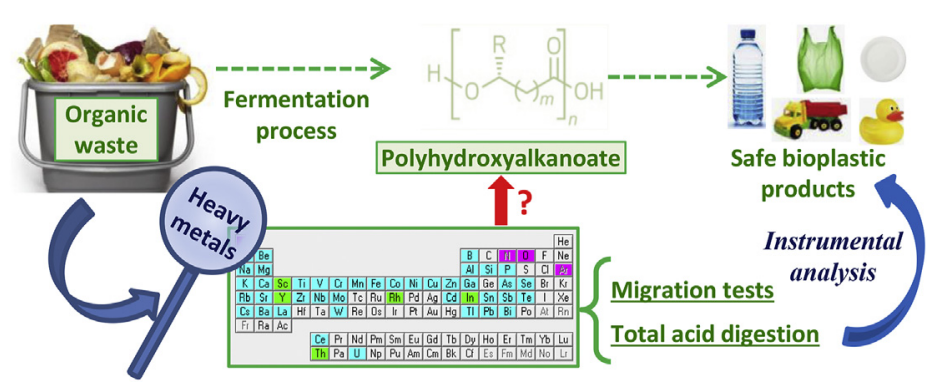

\begin{abstract}
A B S T R A C T
In line with the Circular Economy approach, the production of polyhydroxyalkanoate (PHA) with organic waste as the feedstock may a biotechnological application to reduce waste and recover high-value materials. The potential contaminants that could transfer from bio-waste to a PHA include inorganic elements, such as heavy metals. Hence, the total content and migratability of certain elements were evaluated in several PHA samples produced from different origins and following different methods. The total content of certain elements in PHA ranged between $0.0001(\mathrm{Be})$ and $49,500 \mathrm{mg} \mathrm{kg}^{-1}(\mathrm{Na})$. The concentrations of some alkaline ( $\mathrm{Na}$ and $\mathrm{K}$ ) and alkaline earth $(\mathrm{Ca}$ and $\mathrm{Mg}$ ) metals were highest, which are of little environmental concern. The feedstock type and PHA stabilisation and extraction procedures affected the element contents. Several sets of experiments were conducted to evaluate the migration of elements from the PHA samples under different storage times, temperatures, and pH levels. The total contents of some heavy metals (As, Cd, $\mathrm{Fe}, \mathrm{Hg}, \mathrm{Ni}, \mathrm{Pb}$, and $\mathrm{Zn}$ ) in PHA produced from fruit waste or crops (commercial PHA) were lower than those in the PHA samples produced from the mixture of the organic fraction of municipal waste and sludge from wastewater treatment. Both the PHA obtained by extraction from wet biomass (acid storage) with aqueous phase extraction reagents and commercial PHA were below the migration limits stipulated by the current Toy Safety Directive and by Commission Regulation (EU) October 2011 on plastic materials and articles intended to come into contact with food under frozen and refrigerated conditions.
\end{abstract}

(C) 2020 Elsevier Ltd. All rights reserved.

\footnotetext{
* Corresponding author.

E-mail address: marialuisa.astolfi@uniroma1.it (M.L. Astolfi).
} 


\section{Introduction}

Polyhydroxyalkanoates (PHAs) can be considered to be the sustainable polymers of the future due to their physicochemical properties, biodegradability, and biocompatibility (Kourmentza et al., 2017; Tsang et al., 2019; Valentino et al., 2017). In line with the Circular Economy approach (European Commission, 2015), the production of PHAs may be a biotechnological application to reduce waste through reuse and recovering high-value substances. PHAs are naturally polymerised by bacteria using organic waste as a lowcost carbon source (Khiewwijit et al., 2015; Kourmentza et al., 2017). In recent years, the organic fraction of municipal solid waste has been used as a new feedstock for microorganism-based PHA production, which has become a valuable strategy for reducing biopolymer production costs and increasing their sustainability (Valentino et al., 2018; Valentino et al. 2019a, 2019b).

One of the main concerns relating to the use of waste as a raw material is the content of priority pollutants that can migrate from the waste, through the technology chain, and into the end-products (i.e., PHA). The possible chemical contaminants include inorganic elements, such as heavy metals. In recent years, ecological and public health concerns associated with environmental contamination by these elements have increased (Astolfi et al., 2019a; He et al., 2005). Heavy metal (As, Cd, Hg, and $\mathrm{Pb}$ ) toxicity can damage the functioning of the brain, lungs, kidney, liver, blood composition, and other important organs (Alina et al., 2012; Chowdhury et al., 2000; Henson and Chedrese, 2004; Martin and Griswold, 2009; Smith et al., 2000). Repeated long-term exposure to some metals and their compounds may even cause cancer (Järup, 2003). Toxic elements can originate from geogenic, industrial, agricultural, pharmaceutical, domestic, and atmospheric sources (Astolfi et al., 2017, 2006; Canepari et al., 2018; Manigrasso et al., 2019; Marconi et al., 2011; Vitali et al., 2019). Sources of heavy metals from household municipal solid waste include household dust, batteries, disposable household materials, paints and inks, body care products and medicines, and household pesticides (Bardos, 2004). Significant concentrations of heavy metals are also present in industrial wastewater and municipal sludge (Altaş, 2009).

Under waste law, Italy has a national end-of-waste system that regulates the procedure for the authorisation of certain nonhazardous waste recovery options and establishes the conditions under which biodegradable waste can cease to be considered waste (Italian Regulation, 1998).

The European Commission has issued several directives on plastic materials, including Directive 94/62/EC Packaging and Packaging waste (European Parliament, Council of the European Union, 1994), Directive 2009/48/EC on the safety of toys (European Parliament, Council of the European Union, 2009), and Commission Regulation (EU) No October 2011 on plastic materials and articles intended to come into contact with food (European Commission, 2011). In particular, the presence of $\mathrm{As}, \mathrm{Cd}, \mathrm{Cr}, \mathrm{Hg}$, and $\mathrm{Pb}$ in plastics is regulated by Annex XVII of the EU REACH Regulation on chemicals (European Parliament, Council of the European Union, 2006). Moreover, Directive 2009/48/EC on the safety of toys specifies limits for the migration of 19 elements ( $\mathrm{Al}$, $\mathrm{Sb}, \mathrm{As}, \mathrm{Ba}, \mathrm{B}, \mathrm{Cd}, \mathrm{Cr}(\mathrm{III}), \mathrm{Cr}(\mathrm{VI}), \mathrm{Co}, \mathrm{Cu}, \mathrm{Pb}, \mathrm{Mn}, \mathrm{Hg}, \mathrm{Ni}, \mathrm{Se}, \mathrm{Sr}, \mathrm{Sn}$, organic $\mathrm{Sn}$, and $\mathrm{Zn}$ ) from toy materials and parts.

To our knowledge, the elements of PHA biopolymers have not yet been determined. This study describes the first investigation of the occurrence and migratability of heavy metals and other elements in several PHA samples with different sources and produced following different process steps. The contents of 40 elements ( $\mathrm{Al}$, As, B, Ba, Be, Bi, Ca, Cd, Ce, Co, Cr, Cs, Cu, Fe, Ga, K, La, Li, Mg, Mn, Mo,
Na, Nb, Ni, P, Pb, Rb, Sb, Se, Si, Sn, Sr, Te, Ti, Tl, U, V, W, Zn, and Zr) and $\mathrm{Hg}$ were quantified by inductively coupled plasma mass spectroscopy (ICP-MS) and cold-vapour generation atomic fluorescence spectrometry (CV-AFS), respectively. Although there is currently no specific PHA regulation, our results were compared with current regulations and guidelines for similar materials and/or applications.

\section{Materials and methods}

\subsection{PHA samples}

Two types of feedstock were considered, including a) a mixture of the organic fraction of municipal solid waste and biological sludge from urban wastewater treatment (collected from the Treviso pilot plant in Italy; PHA TV) and b) fruit waste (collected in from Lisbon pilot plant in Portugal; PHA L). Details regarding the production of PHA TV have been reported in previous studies (Valentino et al., 2019a, 2019b). The production of PHA L was similar to that for PHA TV. The main difference was the type of feedstock, which was organic waste originating from fruit processing.

The extraction step of the production technologies (especially PHA extraction from biomass) received the most attention. Thus, both PHA-rich biomass before extraction and purified PHA after extraction from biomass were considered. Three different types of extraction for the latter were considered.

After PHA accumulation, the PHA-rich biomass was stabilised for storage via overnight thermal drying (biomass from Treviso only; PHA TV-d) or acidification with $\mathrm{H}_{2} \mathrm{SO}_{4}$ (biomass from both Treviso and Lisbon; PHA TV-a and PHA L-a, respectively).

For the type-a) feedstock samples, four different PHA samples were analysed: 1) raw PHA-rich biomass (dried biomass, no extraction; PHA TV- $d$-ne); 2) PHA after extraction from dried biomass with $\mathrm{CHCl}_{3}$ (reference method; PHA TV-d-CHCl3); 3) PHA after extraction from dried biomass with $\mathrm{NaClO}$ (PHA TV-d-NaClO); and 4) PHA after extraction from wet biomass (acid storage) with aqueous-phase extraction (PHA TV-a-ap). For each type, at least two different samples were collected from the pilot plant at different operation times.

For the type-b) feedstock samples, one type of PHA sample was analysed, i.e., PHA after extraction from wet biomass (acid storage) with aqueous-phase extraction reagents (PHA L-a-ap).

Overall, 24 different PHA samples produced under six different conditions were analysed. For comparison, three types of commercial PHA obtained from different producers (PHA comm) that were produced from fruit waste or crops were analysed, and their results were expressed as the average.

\subsection{Materials and reagents}

Analytical reagent-grade concentrated $\mathrm{HNO}_{3}$ (67-70\%; superpure) was obtained from Carlo Erba Reagents S.r.l. (Milan, Italy), $\mathrm{CH}_{3} \mathrm{COOH}$ (100\%; superpure) was purchased from Merck KGaA (Darmstadt, Germany), while $\mathrm{HCl}$ (assay $>36 \%$; residue $<3 \mathrm{mg} \mathrm{L}^{-1}$ ) and $\mathrm{H}_{2} \mathrm{O}_{2}$ (assay >30\%) were obtained from Promochem, LGC Standards GmbH (Wesel, Germany).

The $5 \% \mathrm{HCl}$ was used as a carrier, and $0.05 \% \mathrm{NaBH}_{4}$ (SigmaAldrich Chemie $\mathrm{GmbH}$, St. Louis, USA) in $0.05 \% \mathrm{NaOH}$ (assay $>98 \%$, anhydrous pellets, RPE for analysis, ACS - ISO; Carlo Erba Reagents, Milan, Italy) was used as a reducing agent for CV-AFS.

Deionised water (resistivity $\leq 18.3 \mathrm{M} \Omega \mathrm{cm}$ ) was obtained using an Arioso Power I RO-UP Scholar UV system from Human Corporation (Songpa-Ku, Seoul, Korea). Graduated tubes (2.5-5-10 mL in polypropylene) were purchased from Artiglass S.r.l. (Due Carrare, 
PD, Italy). Syringe filters with cellulose nitrate membranes (GVS Filter Technology, Indianapolis, USA; pore size, $0.45 \mu \mathrm{m}$ ) were used to filter the samples prior to analysis.

All plastic containers, polypropylene tubes, pipette tips, quartz digestion tubes, and reagents that came into contact with the samples or standards were checked for contamination.

\subsection{Standard solutions}

An ICP-MS multi-element standard solution $\left(1.000 \pm 0.005 \mathrm{mg} \mathrm{L}^{-1} \mathrm{As}, \mathrm{Al}, \mathrm{Ba}, \mathrm{Be}, \mathrm{Bi}, \mathrm{Cd}, \mathrm{Cr}, \mathrm{Cs}, \mathrm{Cu}, \mathrm{Ga}, \mathrm{La}, \mathrm{Li}, \mathrm{Mn}\right.$, $\mathrm{Mo}, \mathrm{Nb}, \mathrm{Ni}, \mathrm{Pb}, \mathrm{Rb}, \mathrm{Sb}, \mathrm{Se}, \mathrm{Sn}, \mathrm{Te}, \mathrm{Ti}, \mathrm{Tl}, \mathrm{U}, \mathrm{V}, \mathrm{W}$, and $\mathrm{Zr}$; $5.00 \pm 0.03 \mathrm{mg} \mathrm{L}^{-1} \mathrm{Ce}$ and $\mathrm{Co} ; 10.00 \pm 0.05 \mathrm{mg} \mathrm{L}^{-1} \mathrm{Fe}$ and $\mathrm{Zn}$; $50.00 \pm 0.25 \mathrm{mg} \mathrm{L}^{-1} \mathrm{P}$ and $\mathrm{Si} ; 55.00 \pm 0.25 \mathrm{mg} \mathrm{L}^{-1} \mathrm{~B}$ and $\mathrm{Sr}$; $500.0 \pm 2.5 \mathrm{mg} \mathrm{L}^{-1} \mathrm{~K}, \mathrm{Mg}$, and $\mathrm{Na}$; and $1000 \pm 5 \mathrm{mg} \mathrm{L}^{-1} \mathrm{Ca}$ ) was purchased from Ultra Scientific/Agilent Technologies (North Kingstown, RI, USA), while a CV-AFS standard solution of $\mathrm{Hg}$ $\left(1002 \pm 7 \mathrm{mg} \mathrm{L}^{-1}\right)$ was obtained from SCP Science (Baie D'Urfé, Canada). All standard solutions were diluted with the same percentage of acid present in the samples [3\% (v/v) $\mathrm{HNO}_{3}$ for the digests, and $1 \%(\mathrm{v} / \mathrm{v}) \mathrm{HNO}_{3}, 3 \%(\mathrm{v} / \mathrm{v}) \mathrm{CH}_{3} \mathrm{COOH}$, or $0.07 \mathrm{M} \mathrm{HCl}$ for the extracts obtained by the migration tests].

To maintain the daily ICP-MS performance, a multi-standard tuning solution with $0.005 \mathrm{mg} \mathrm{L}^{-1}$ of $\mathrm{Ba}, \mathrm{Be}, \mathrm{Ce}, \mathrm{Co}, \mathrm{In}, \mathrm{Pb}, \mathrm{Mg}, \mathrm{Tl}$, and Th was prepared from a multi-standard stock solution $\left(10.00 \pm 0.05 \mathrm{mg} \mathrm{L}^{-1}\right)$ obtained from Spectro Pure/Ricca Chemical Company (Arlington, TX, USA). A standard solution of $\mathrm{Y}$ (at $0.005 \mathrm{mg} \mathrm{L}^{-1}$ from $1000 \pm 2 \mathrm{mg} \mathrm{L}^{-1}$ ), purchased from Panreac Química (Barcelona, Spain), and a multi-element standard solution of Sc, Rh, In, and Th (at $0.010 \mathrm{mg} \mathrm{L}^{-1}$ from $1000 \pm 5 \mathrm{mg} \mathrm{L}^{-1}$ ), obtained from Merck KGaA (Darmstadt, Germany), in $1 \%(\mathrm{v} / \mathrm{v}) \mathrm{HNO}_{3}$ were employed as the internal standards to control the nebuliser efficiency, as previously reported (Astolfi et al., 2020a, 2020b).

A solution of trace SRM 1643e elements in water (National Institute of Standards and Technology, NIST; Gaithersburg, MD, USA) was used for quality control.

\subsection{Instrumentation}

A quadrupole ICP-MS (820-MS Bruker; Bremen, Germany) equipped with a collision-reaction interface (CRI) and glass nebuliser (0.4 mL min ${ }^{-1}$; MicroMistTM; Analytik Jena AG, Jena, Germany) was used to analyse all elements, excluding $\mathrm{Hg}$, which was analysed by CV-AFS (AFS 8220 Titan, FullTech Instruments; Rome, Italy). The operating parameters for the ICP-MS and CV-AFS analyses are summarised in Table S1 and are detailed in previous studies (Astolfi et al., 2020a, 2020b, 2019b).

A Gibertini Elettronica (Milan, Italy) Europe 60 analytical balance (sensitivity, $0.1 \mathrm{mg}$ ) was used to weigh all samples.

A Milestone (FKV; Sorisole, Bergamo, Italy) Ethos1 Touch Control microwave system was used for acid digestion, and a water bath (WB12; Argo Lab, Modena, Italy) with electronic temperature control was used for the migration tests.

\subsection{Sample preparation}

\subsubsection{Total acid digestion}

Weighed amounts ( $\sim 50 \mathrm{mg}$ or $\sim 200 \mathrm{mg}$ for CV-AFS or ICP-MS analysis, respectively) of the PHA samples were transferred into quartz vessels; to these, $1 \mathrm{~mL} 67 \% \mathrm{HNO}_{3}, 0.5 \mathrm{~mL} 30 \% \mathrm{H}_{2} \mathrm{O}_{2}$, and $1.5 \mathrm{~mL}$ deionised water were added. The resulting solutions were subsequently heated with microwave energy for $40 \mathrm{~min}$. The following heating program was used: first step, heating to $50{ }^{\circ} \mathrm{C}$ for $5 \mathrm{~min}$; second step, hold temperature at $50^{\circ} \mathrm{C}$ for $5 \mathrm{~min}$; third step, heating to $100{ }^{\circ} \mathrm{C}$ for $5 \mathrm{~min}$; fourth step, hold temperature at $100{ }^{\circ} \mathrm{C}$ for $5 \mathrm{~min}$; fifth step, heating to $150{ }^{\circ} \mathrm{C}$ for $5 \mathrm{~min}$; sixth step, hold temperature at $150{ }^{\circ} \mathrm{C}$ for $5 \mathrm{~min}$; seventh step, heating to $180^{\circ} \mathrm{C}$ for $5 \mathrm{~min}$; and eighth step, hold temperature at $180^{\circ} \mathrm{C}$ for $15 \mathrm{~min}$. Prior to use, the quartz vessels were cleaned with the same reagents and digestion program used for the PHA samples, rinsed with deionised water, and thoroughly dried with absorbent paper. The solutions obtained from digestion were diluted to $5 \mathrm{~mL}$ with $3 \% \mathrm{HCl}$ or $10 \mathrm{~mL}$ with deionised water and filtered for CV-AFS or ICP-MS analysis, respectively. Prior to ICP-MS analysis, the digests were further diluted $1: 10$ and $1: 50$ with deionised water.

Blanks $\left(3 \% \mathrm{HNO}_{3}\right)$ were periodically analysed alongside the samples to check for any losses or cross-contamination.

\subsubsection{Migration tests}

Ten blank solutions were tested with each sample set extracted during the different migration tests to subtract the background signal from the reagents and trace and control the contributions from possible sample contamination. The blanks were deducted from all measurements. The procedure for each treatment is detailed in the following sections. At the end of each migration test, the solution was filtered and analysed by CV-AFS or ICP-MS. Prior to CV-FS analysis, the extracts were further diluted with $6 \% \mathrm{HCl}$ in a ratio of $1: 2$

2.5.2.1. $\mathrm{H}_{2} \mathrm{O}$ treatment experiments. Weighed amounts $(\sim 25 \mathrm{mg})$ of the PHA samples were transferred into polypropylene tubes, to which $5 \mathrm{~mL}$ of deionised $\mathrm{H}_{2} \mathrm{O}(\mathrm{pH} \sim 7)$ was added. The tubes were then covered with a cap and heated at $70{ }^{\circ} \mathrm{C}$ for $2 \mathrm{~h}$ or stored in the dark at $20^{\circ} \mathrm{C}$ for 10 days.

2.5.2.2. $\mathrm{CH}_{3} \mathrm{COOH}$ treatment experiments. Weighed amounts $(\sim 25 \mathrm{mg})$ of the PHA samples were extracted in dilute $\mathrm{CH}_{3} \mathrm{COOH}$ (food simulant $\mathrm{B} ; \mathrm{pH} \sim 4.5$ ) according to Commission Regulation (EU) No October 2011 (European Commission, 2011) on plastic materials and articles intended to come into contact with food. Five millilitres of a $3 \% \mathrm{CH}_{3} \mathrm{COOH}$ solution, simulating food with a $\mathrm{pH}$ below 4.5, were pipetted into each tube with the PHA samples, which were then capped and placed in a water bath at $70^{\circ} \mathrm{C}$ for $2 \mathrm{~h}$ or stored in the dark at $20^{\circ} \mathrm{C}$ for 10 days.

2.5.2.3. HCl treatment experiments. Weighed amounts ( $25 \mathrm{mg})$ of the PHA samples were transferred into polypropylene tubes mixed with $5 \mathrm{~mL}$ of $0.07-\mathrm{M} \mathrm{HCl}$ and then heated in a water bath for $2 \mathrm{~h}$ to $37^{\circ} \mathrm{C}$ according to European standard EN 71-3 (British Standards Institution (BSI), 1994).

\subsection{Method performance}

Method performance parameters, such as the trueness [per cent bias (\%bias) or recovery (\%R)], precision (intraday and interday within-laboratory precision), linearity range, and detection and quantification limits (LODs and LOQs, respectively), were assessed. Fortified PHA TV-a-ap samples were used for the quality control of the total digestion treatment, while a fortified reference water solution (SRM 1643e) was used for the migration tests. Detailed information on the calibration graphs and quality control for elemental analysis was shown in the Supplementary Material. Briefly, the instruments were calibrated externally using mixed standards prepared by serial dilution in the same matrix as the final samples $\left(3 \% \mathrm{HNO}_{3}\right.$ for digests, and $1 \% \mathrm{HNO}_{3}, 3 \% \mathrm{CH}_{3} \mathrm{COOH}$, and $0.07 \mathrm{M} \mathrm{HCl}$ for extracts). The linear ranges of the 41 elements examined in this study are listed in Table S2.

Owing to the lack of certified reference materials and a blank matrix for PHA biopolymers, the analytical quality control was 
verified by conducting recovery experiments. The obtained recoveries of the spiked PHA samples ranged from 90 to $102 \%$ (Table S2), confirming that there was no significant loss during digestion or contamination, or interference during analysis.

A reference water solution (SRM 1643) was fortified with $2 \mu \mathrm{g} \mathrm{L}^{-1} \mathrm{Hg} ; 25 \mu \mathrm{g} \mathrm{L}^{-1} \mathrm{Ce}, \mathrm{Cs}, \mathrm{Ga}, \mathrm{La}, \mathrm{Nb}, \mathrm{Sn}, \mathrm{Ti}, \mathrm{U}, \mathrm{W}$, and $\mathrm{Zr}$; and $2500 \mu \mathrm{g} \mathrm{L}^{-1} \mathrm{P}$ and $\mathrm{Si}$ to assess the quality of the analysis of extracts obtained by the migration tests. Fortified SRM 1643e was analysed after each calibration curve and revealed element concentrations that were within $10 \%$ of the certified values and ranged from 90 to $96 \%$ of spiked elements, excluding $\mathrm{Al}, \mathrm{As}, \mathrm{Ba}$, Se, and Te (within $15 \%$; Table S2).

The method was determined to be within-laboratory precision, both intra-day (repeatability) and inter-day (reproducibility), at the concentration used for the recovery study by calculating the per cent coefficient of variation (\%CV). Three spiked samples were analysed on the same day to assess the repeatability and on three different days to assess the reproducibility. The results are listed in Table S2.

The LODs and LOQs were calculated as three and ten times the standard deviation of the blank samples, respectively (Table S3). The method blanks were treated as samples to subtract the background signal from the reagents. The LODs and LOQs ranged from 0.0001 (Be and $\mathrm{Nb}$ ) to $100 \mathrm{mg} \mathrm{kg}^{-1}$ (Ca) and 0.0004 (Be) to $350 \mathrm{mg} \mathrm{kg}^{-1}$ (Ca), respectively.

\subsection{Statistical analysis}

Statistical analyses were conducted using IBM SPSS Statistics 25 software (IBM Corp., Armonk, NY, USA). For each element, values below the LOD were replaced with a value equal to half the LOD. When the percentage of values < LOD exceeded $20 \%$, the element was excluded from the statistical elaboration.

The differences in the PHA concentration were tested by Kruskal-Wallis and pairwise post-hoc tests. The results (Table 1) were considered to be statistically significant with p-values of $<0.05$.

\section{Results and discussion}

\subsection{Total elemental content}

Table 1 shows the results of the Kruskal Wallis test, which was conducted to verify the presence and concentrations of differences elements among the six different types of PHA samples. $\mathrm{Nb}$ exhibited no significant differences between all of the PHA samples, while the levels of $\mathrm{Bi}, \mathrm{Se}, \mathrm{Te}, \mathrm{Tl}, \mathrm{V}, \mathrm{W}$, and $\mathrm{Zr}$ were very low or below the LODs, with an inadequate number of observations for multivariate analysis (Table 1 ). Thus, these elements were eliminated from the multivariate analysis data set.

Focusing on PHA-rich biomass with no extraction (PHA content around $50 \% \mathrm{w} / \mathrm{w}$, after thermal drying), the concentrations of alkaline and alkaline earth metals were highest, with the levels of $\mathrm{Na}, \mathrm{Ca}, \mathrm{Mg}$, and $\mathrm{K}$ ranging between $0.2 \%$ and $5 \%$ on a dry-weight basis. Furthermore, $\mathrm{P}$ was present at a concentration of approximately $0.4 \%$, while Fe and $\mathrm{Mn}$ were present at concentrations of approximately $0.1 \%$ and $0.01 \%$, respectively. However, all of these elements are of no or little concern from environmental or health viewpoints. $\mathrm{Zn}$ was the heavy metal present at the highest concentration of approximately $300 \mathrm{mg} \mathrm{kg}^{-1}(0.03 \%)$. The concentration of $\mathrm{Cu}$ was approximately $70 \mathrm{mg} \mathrm{kg}^{-1}(0.007 \%)$, while those of other toxic metals, such as $\mathrm{Ni}$ and $\mathrm{Pb}$, were below $10 \mathrm{mg} \mathrm{kg}^{-1}$ (0.001\%). Moreover, Cd is below $0.1 \mathrm{mg} \mathrm{kg}^{-1}(0.00001 \%)$. The contents of metalloids, such as and Se, were below $1 \mathrm{mg} \mathrm{kg}^{-1}$ $(0.0001 \%)$.
PHA extraction from dried biomass using hypochlorite destroys the organic matter, causing it to concentrate or dilute the metals, depending on how strongly sorbed to the remaining solid phase they are. For example, the contents of $\mathrm{Al}, \mathrm{As}, \mathrm{Hg}, \mathrm{K}, \mathrm{Na}, \mathrm{Mo}$, and $\mathrm{U}$ were strongly reduced, while those of $\mathrm{Cd}, \mathrm{Fe}, \mathrm{Mn}, \mathrm{Pb}$, and $\mathrm{Zn}$ were increased. Furthermore, chloroform dissolves the PHA, causing the metals to remain in the residual solid phase, i.e., chloroform extraction also acts as a method of purifying PHA from inorganic elements ( $\mathrm{Ca}, \mathrm{Cd}, \mathrm{Cu}, \mathrm{Mn}, \mathrm{Na}, \mathrm{Rb}, \mathrm{Sr}$, and $\mathrm{Zn}$ ). The contents of all investigated elements decreased, excluding $\mathrm{B}, \mathrm{Cr}, \mathrm{Nb}, \mathrm{Sb}, \mathrm{Se}, \mathrm{Te}, \mathrm{Tl}$, $\mathrm{V}, \mathrm{W}$, and $\mathrm{Zr}$, which were already at a low concentration.

The metal concentrations of biomass that underwent extraction after acid stabilisation and aqueous-phase extraction were typically lower than those of biomass that underwent stabilisation by thermal drying. This could be expected as inorganic elements were retained in the solid phase during thermal drying, while they could be desorbed more easily in the liquid phase during acidic stabilisation.

The effects of different feedstock types (municipal waste/sludge vs fruit waste) under the same acid stabilisation and aqueous-phase extraction were compared. The comparison of PHA TV-a-ap and PHA L-a-ap indicates that more inorganic elements are present in the PHA derived from municipal waste/sludge than that derived from fruit waste (excluding $\mathrm{As}, \mathrm{Na}$, and $\mathrm{Si}$, although the difference was not significant). The concentration of inorganic elements in commercial PHA, which is industrially obtained from crop substrates, is usually lower than that of waste-based PHA.

The contents of some environmentally relevant elements ( $\mathrm{Al}, \mathrm{As}$, $\mathrm{Cd}, \mathrm{Hg}, \mathrm{Ni}, \mathrm{Pb}$, and $\mathrm{Zn}$ ) were highest in the PHA derived from municipal waste. This was not surprising, as this source also included a significant fraction of sludge from wastewater treatment (approximately one-third). However, there are still environmental benefits to recovering organic carbon from waste in the form of biodegradable plastics that can counteract the higher level of contaminants, if the content of contaminants is sufficiently low. The contents of most relevant contaminants were at the $\mathrm{mg} \mathrm{kg}^{-1}$ or $\mu \mathrm{g}$ $\mathrm{kg}^{-1}$ level, which can be considered acceptable. The European Commission has issued several directives on requirements for plastic materials intended to be used in different ways, such as Directive 94/62/EC on packaging and packaging waste (European Parliament, Council of the European Union, 1994), Directive 2009/ 48/EC on the safety of toys (European Parliament, Council of the European Union, 2009), and Commission Regulation (EU) No October 2011 on plastic materials and articles intended to come into contact with food (European Commission, 2011). In particular, Annex II of Directive 94/62/EC (European Parliament, Council of the European Union, 1994) on packaging and packaging waste determines the essential requirements that all packaging on the market within the European Community should comply with. Article 11 of Directive 94/62/EC (European Parliament, Council of the European Union, 1994) states that Member States shall ensure that the sum of the concentrations of $\mathrm{Pb}, \mathrm{Cd}, \mathrm{Hg}$, and $\mathrm{Cr}(\mathrm{VI})$ in packaging or packaging components shall not exceed $100 \mathrm{mg} \mathrm{kg}$. The sum of these metals was well below this level in selected PHA samples.

According to regulation 1907/2006/EC (European Parliament, Council of the European Union, 2006), Cd contamination receives particular attention, and the regulation states that mixtures and articles composed of plastic materials shall not be placed on the market if the concentration of $\mathrm{Cd}$ is equal to or greater than $0.01 \%$ $\left(100 \mathrm{mg} \mathrm{kg}^{-1}\right)$ of the plastic material. The Cd contents of all wastebased PHA samples in our study are well below this limit. Commission Regulation (EU) No October 2011 establishes a set of specific requirements for PHA obtained through microbial fermentation by using Alcaligenes eutrophus. According to this 
Table 1

Number of valid data $(\mathrm{N})$, descriptive statistics $\left(\mathrm{mg} \mathrm{kg}^{-1}\right)$ and Kruskal-Wallis test for each analysed element in the different PHA samples.

\begin{tabular}{|c|c|c|c|c|c|c|c|c|c|c|c|c|c|c|c|c|c|c|c|}
\hline \multicolumn{2}{|c|}{$\begin{array}{l}\text { Types of } \\
\text { feedstock }\end{array}$} & \multicolumn{12}{|c|}{ Municipal waste/sludge } & \multirow{2}{*}{\multicolumn{3}{|c|}{$\begin{array}{l}\text { Fruit waste } \\
\text { PHA L-a-ap }\end{array}$}} & \multirow{2}{*}{\multicolumn{3}{|c|}{$\begin{array}{l}\text { Crops } \\
\text { PHA comm }^{\mathrm{f}}\end{array}$}} \\
\hline \multirow[t]{2}{*}{ Element } & \multirow[t]{2}{*}{$\mathrm{N}$} & \multicolumn{3}{|c|}{ PHA TV- $d$-ne ${ }^{a}$} & \multicolumn{3}{|c|}{ PHA TV- $d-\mathrm{CHCl}_{3}{ }^{\mathrm{b}}$} & \multicolumn{3}{|c|}{ PHA TV- $d-\mathrm{NaClO}^{c}$} & \multicolumn{3}{|c|}{ PHA TV-a-ap $^{d}$} & & & & & & \\
\hline & & Median & Mean & SD & Median & Mean & SD & Median & Mean & SD & Median & Mean & SD & Median & Mean & SD & Median & Mean & SD \\
\hline Al & 23 & $548^{\mathrm{f,c}}$ & 1090 & 1500 & 52 & 49 & 37 & $9.6^{\mathrm{a}}$ & 9.0 & 5.9 & $51^{\mathrm{f}}$ & 52 & 33 & 6.11 & 6.11 & 0.92 & $2.76^{\mathrm{a}, \mathrm{d}}$ & 2.76 & 0.62 \\
\hline As & 20 & $0.79^{\mathrm{d}, \mathrm{e}, \mathrm{f}}$ & 0.73 & 0.13 & 0.145 & 0.152 & 0.096 & $0.206^{d}$ & 0.213 & 0.091 & $0.029^{\mathrm{a}, \mathrm{c}}$ & 0.035 & 0.018 & $0.072^{\mathrm{a}}$ & 0.072 & 0.070 & $0.028^{\mathrm{a}}$ & 0.036 & 0.019 \\
\hline B & 19 & $4.2^{\mathrm{f}}$ & 4.5 & 1.1 & $5.0^{f}$ & 10 & 11 & $4.1^{\mathrm{f}}$ & 5.5 & 2.6 & 2.1 & 3.2 & 3.0 & 1.93 & 1.93 & 0.19 & $<1^{\mathrm{a}, \mathrm{b}, \mathrm{c}}$ & $<1$ & - \\
\hline Ba & 21 & $28^{e, f}$ & 23 & 15 & 2.2 & 2.6 & 1.3 & $28^{\mathrm{d}, \mathrm{e}, \mathrm{f}}$ & 38 & 28 & $1.92^{\mathrm{c}}$ & 1.89 & 0.59 & $1.31^{\mathrm{a}, \mathrm{c}}$ & 1.31 & 0.30 & $<1^{\mathrm{a}, \mathrm{c}}$ & $<1$ & - \\
\hline $\mathrm{Be}$ & 18 & $0.031^{\mathrm{b}, \mathrm{f}}$ & 0.027 & 0.018 & $<0.0001^{\mathrm{a}, \mathrm{c}}$ & $<0.0001$ & - & $0.053^{\mathrm{b}, \mathrm{e}, \mathrm{f}}$ & 0.056 & 0.025 & 0.0032 & 0.0043 & 0.0032 & $0.000657^{c}$ & 0.000657 & 0.000071 & $<0.0001^{\mathrm{a}, \mathrm{c}}$ & $<0.0001$ & - \\
\hline $\mathbf{B i}$ & 12 & 0.16 & $<0.02$ & - & $<0.02$ & $<0.02$ & - & 0.52 & 0.41 & 0.27 & $<0.02$ & $<0.02$ & - & $<0.02$ & $<0.02$ & - & $<0.02$ & $<0.02$ & - \\
\hline $\mathrm{Ca}$ & 24 & $20,400^{\mathrm{d}, \mathrm{f}}$ & 19,200 & 7600 & $827^{c}$ & 848 & 220 & $28,900^{c, d, e, f}$ & 28,000 & 2500 & $393^{\mathrm{a}, \mathrm{c}}$ & 719 & 850 & $467^{c}$ & 467 & 320 & $422^{\mathrm{a}, \mathrm{c}}$ & 420 & 8.7 \\
\hline Cd & 17 & $0.101^{\mathrm{d}, \mathrm{e}, \mathrm{f}}$ & 0.096 & 0.070 & $0.015^{c}$ & 0.019 & 0.015 & $0.36^{\mathrm{b}, \mathrm{d}, \mathrm{e}, \mathrm{f}}$ & 0.37 & 0.22 & $<0.005^{\mathrm{a}, \mathrm{c}}$ & 0.0088 & 0.0085 & $<0.005^{a, c}$ & $<0.005$ & - & $<0.005^{\mathrm{a}, \mathrm{c}}$ & 0.006 & 0.003 \\
\hline $\mathrm{Ce}$ & 21 & $0.66^{f}$ & 0.57 & 0.42 & $0.062^{c}$ & 0.073 & 0.042 & $1.29^{\mathrm{b}, \mathrm{d}, \mathrm{e}, \mathrm{f}}$ & 1.10 & 0.80 & $0.052^{c}$ & 0.067 & 0.041 & $0.046^{\mathrm{c}}$ & 0.046 & 0.032 & $<0.006^{\mathrm{a}, \mathrm{c}}$ & $<0.006$ & - \\
\hline Co & 21 & $0.46^{\mathrm{b}, \mathrm{d}, \mathrm{f}}$ & 0.46 & 0.13 & $0.03^{\mathrm{a}, \mathrm{c}}$ & $<0.01$ & - & $0.36^{\mathrm{b}, \mathrm{d}, \mathrm{f}}$ & 0.53 & 0.35 & $0.051^{\mathrm{a}, \mathrm{c}}$ & 0.062 & 0.046 & 0.052 & 0.052 & 0.020 & $<0.01^{\mathrm{a}, \mathrm{c}}$ & $<0.01$ & - \\
\hline $\mathrm{Cr}$ & 24 & $3.2^{\mathrm{b}}$ & 2.8 & 1.1 & $0.53^{\mathrm{a}, \mathrm{c}}$ & 0.55 & 0.16 & $2.64^{\mathrm{b}}$ & 2.66 & 0.70 & 2.6 & 4.2 & 4.2 & 0.95 & 0.95 & 0.49 & 1.3 & 1.2 & 1.0 \\
\hline Cs & 22 & $0.081^{\mathrm{b}, \mathrm{f}}$ & 0.071 & 0.051 & $0.0013^{a, c}$ & 0.0023 & 0.0021 & $0.076^{\mathrm{b}, \mathrm{f}}$ & 0.085 & 0.064 & 0.0059 & 0.0065 & 0.0042 & 0.0036 & 0.0036 & 0.0016 & $<0.0004^{\mathrm{a}, \mathrm{c}}$ & $<0.0004$ & - \\
\hline $\mathrm{Cu}$ & 24 & $50^{\mathrm{b}, \mathrm{f}}$ & 74 & 43 & $3.3^{\mathrm{a}, \mathrm{c}}$ & 3.8 & 1.5 & $77^{\mathrm{b}, \mathrm{f}}$ & 88 & 23 & 18 & 22 & 18 & 14 & 14 & 13 & $0.211^{\mathrm{a}, \mathrm{c}}$ & 0.203 & 0.057 \\
\hline $\mathrm{Fe}$ & 24 & $779^{e, f}$ & 805 & 590 & $43.5^{c}$ & 45.0 & 5.1 & $1430^{\mathrm{b}, \mathrm{d}, \mathrm{e}, \mathrm{f}}$ & 1660 & 1200 & $82^{c}$ & 77 & 35 & $19.4^{\mathrm{a}}$ & 19.4 & 4.3 & $22^{a, c}$ & 19 & 17 \\
\hline Ga & 21 & $0.20^{b, f}$ & 0.29 & 0.28 & $0.011^{\mathrm{a}, \mathrm{c}}$ & 0.014 & 0.012 & $0.35^{\mathrm{b}, \mathrm{f}}$ & 0.38 & 0.21 & 0.087 & 0.086 & 0.031 & 0.0490 & 0.0490 & 0.0092 & $<0.001^{\mathrm{a}, \mathrm{c}}$ & $<0.001$ & - \\
\hline $\mathrm{Hg}$ & 24 & $0.22^{\mathrm{d}, \mathrm{e}, \mathrm{f}}$ & 0.18 & 0.12 & 0.023 & 0.025 & 0.017 & $0.066^{\mathrm{e}, \mathrm{f}}$ & 0.071 & 0.020 & $0.012^{\mathrm{a}}$ & 0.023 & 0.027 & $0.0062^{\mathrm{a,c}}$ & 0.0062 & 0.0053 & $0.0034^{\mathrm{a}, \mathrm{c}}$ & 0.0033 & 0.0020 \\
\hline $\mathbf{K}$ & 23 & $1810^{\mathrm{b}, \mathrm{c}, \mathrm{d}, \mathrm{e}, \mathrm{f}}$ & 2280 & 1700 & $59^{\mathrm{a}}$ & 63 & 22 & $150^{\mathrm{a}}$ & 129 & 56 & $41^{a}$ & 42 & 24 & $29.3^{\mathrm{a}}$ & 29.3 & 9.6 & $18.7^{\mathrm{a}}$ & 21.0 & 5.2 \\
\hline La & 21 & $0.39^{\mathrm{f}}$ & 0.34 & 0.24 & $0.034^{c}$ & 0.041 & 0.025 & $0.80^{b, d, e, f}$ & 0.66 & 0.47 & $0.027^{c}$ & 0.032 & 0.017 & $0.017^{c}$ & 0.017 & 0.015 & $<0.004^{a, c}$ & $<0.004$ & - \\
\hline $\mathbf{L i}$ & 24 & $0.59^{\mathrm{b}, \mathrm{f}}$ & 0.57 & 0.32 & $0.016^{a, c}$ & 0.026 & 0.026 & $0.75^{\mathrm{b}, \mathrm{f}}$ & 0.78 & 0.56 & 0.061 & 0.063 & 0.045 & 0.0230 & 0.0230 & 0.0045 & $0.0042^{\mathrm{a}, \mathrm{c}}$ & 0.0078 & 0.0069 \\
\hline Mg & 24 & $3490^{\mathrm{d}, \mathrm{e}, \mathrm{f}}$ & 4360 & 3300 & 514 & 548 & 350 & $3570^{\mathrm{d}, \mathrm{e}, \mathrm{f}}$ & 6470 & 5600 & $169^{\mathrm{a}, \mathrm{c}}$ & 220 & 160 & $141^{\mathrm{a}, \mathrm{c}}$ & 141 & 23 & $19^{\mathrm{a}, \mathrm{c}}$ & 24 & 10 \\
\hline Mn & 22 & $83^{\mathrm{e}, \mathrm{f}}$ & 75 & 13 & $5.8^{\mathrm{c}}$ & 5.3 & 3.1 & $166^{\mathrm{b}, \mathrm{d}, \mathrm{e}, \mathrm{f}}$ & 171 & 14 & $1.26^{\mathrm{c}}$ & 1.38 & 0.42 & $0.18^{\mathrm{a}, \mathrm{c}}$ & 0.18 & 0.15 & $0.24^{\mathrm{a}, \mathrm{c}}$ & 0.32 & 0.30 \\
\hline Mo & 24 & $0.56^{\mathrm{b}, \mathrm{f}}$ & 0.60 & 0.19 & $0.0173^{\mathrm{a}, \mathrm{c}, \mathrm{d}}$ & 0.0196 & 0.0058 & $0.058^{\mathrm{b}}$ & 0.062 & 0.013 & $0.074^{\mathrm{b}}$ & 0.104 & 0.080 & 0.044 & 0.044 & 0.016 & $0.0262^{a}$ & 0.0247 & 0.0068 \\
\hline $\mathrm{Na}$ & 24 & $49,500^{\mathrm{b}, \mathrm{d}, \mathrm{f}}$ & 51,100 & 36,000 & $205^{\mathrm{a}}$ & 202 & 80 & 753 & 1140 & 870 & $299^{\mathrm{a}}$ & 878 & 1200 & 1290 & 1290 & 190 & $65^{\mathrm{a}}$ & 231 & 290 \\
\hline Nb & 16 & 0.056 & 0.052 & 0.038 & 0.00512 & 0.00538 & 0.00065 & 0.058 & 0.069 & 0.033 & 0.0105 & 0.0103 & 0.0014 & 0.00530 & 0.00530 & 0.00001 & $<0.005$ & $<0.005$ & - \\
\hline $\mathbf{N i}$ & 23 & $9.0^{e, f}$ & 8.7 & 1.3 & $2.23^{\mathrm{c}}$ & 2.24 & 0.62 & $11.3^{\mathrm{b}, \mathrm{d}, \mathrm{e}, \mathrm{f}}$ & 13.5 & 5.9 & $1.7^{\mathrm{c}}$ & 2.3 & 1.8 & $0.55^{\mathrm{a}, \mathrm{c}}$ & 0.55 & 0.22 & $0.093^{\mathrm{a}, \mathrm{c}}$ & 0.072 & 0.043 \\
\hline $\mathbf{P}$ & 24 & $4057^{\mathrm{b}, \mathrm{d}, \mathrm{e}, \mathrm{f}}$ & 4300 & 790 & $341^{\mathrm{a}}$ & 330 & 160 & $3190^{\mathrm{d}, \mathrm{f}}$ & 3020 & 1200 & $64^{\mathrm{a}, \mathrm{c}}$ & 128 & 160 & $108^{\mathrm{a}}$ & 108 & 13 & $24^{\mathrm{a}, \mathrm{c}}$ & 29 & 15 \\
\hline $\mathbf{P b}$ & 21 & $5.9^{\mathrm{f}}$ & 7.4 & 4.2 & $0.73^{c}$ & 0.87 & 0.58 & $26^{\mathrm{b}, \mathrm{e}, \mathrm{f}}$ & 59 & 89 & 2.4 & 3.8 & 4.1 & $0.260^{c}$ & 0.260 & 0.084 & $<0.1^{\mathrm{a}, \mathrm{c}}$ & $<0.1$ & - \\
\hline $\mathbf{R b}$ & 24 & $1.3^{\mathrm{b}, \mathrm{f}}$ & 1.8 & 1.1 & $0.032^{\mathrm{a}, \mathrm{c}}$ & 0.035 & 0.010 & $0.81^{\mathrm{b}, \mathrm{f}}$ & 0.91 & 0.65 & 0.107 & 0.107 & 0.067 & 0.043 & 0.043 & 0.017 & $0.0112^{\mathrm{a}, \mathrm{c}}$ & 0.0116 & 0.0041 \\
\hline $\mathbf{S b}$ & 22 & $0.088^{\mathrm{b}, \mathrm{f}}$ & 0.106 & 0.058 & $0.019^{\mathrm{a}, \mathrm{d}}$ & 0.021 & 0.013 & $0.049^{\mathrm{f}}$ & 0.066 & 0.033 & $0.133^{\mathrm{b}, \mathrm{f}}$ & 0.131 & 0.085 & 0.034 & 0.034 & 0.021 & $<0.002^{\mathrm{a}, \mathrm{c}, \mathrm{d}}$ & $<0.002$ & - \\
\hline Se & 1 & $<0.2$ & $<0.2$ & - & $<0.2$ & $<0.2$ & - & $<0.2$ & $<0.2$ & - & $<0.2$ & $<0.2$ & - & $<0.2$ & $<0.2$ & - & $<0.2$ & $<0.2$ & - \\
\hline $\mathbf{S i}$ & 24 & $855^{\mathrm{b}, \mathrm{f}}$ & 790 & 320 & $181^{\mathrm{a}, \mathrm{c}}$ & 188 & 63 & $686^{\mathrm{b}, \mathrm{f}}$ & 620 & 220 & 329 & 332 & 52 & $564^{\mathrm{f}}$ & 564 & 170 & $125^{\mathrm{a}, \mathrm{c}, \mathrm{e}}$ & 113 & 23 \\
\hline Sn & 24 & $1.06^{\mathrm{f}}$ & 1.01 & 0.79 & $0.101^{c}$ & 0.104 & 0.026 & $1.8^{\mathrm{b}, \mathrm{e}, \mathrm{f}}$ & 2.0 & 1.4 & 0.14 & 0.50 & 0.79 & $0.070^{c}$ & 0.070 & 0.037 & $0.011^{\mathrm{a}, \mathrm{c}}$ & 0.036 & 0.044 \\
\hline $\mathbf{S r}$ & 24 & $110^{\mathrm{d}, \mathrm{e}, \mathrm{f}}$ & 114 & 42 & 4.25 & 4.31 & 0.73 & $112^{\mathrm{d}, \mathrm{e}, \mathrm{f}}$ & 112 & 16 & $3.5^{\mathrm{a}, \mathrm{c}}$ & 6.5 & 6.6 & $2.5^{\mathrm{a}, \mathrm{c}}$ & 2.5 & 1.1 & $0.485^{\mathrm{a}, \mathrm{c}}$ & 0.475 & 0.023 \\
\hline Te & 2 & $<0.005$ & $<0.005$ & - & $<0.005$ & $<0.005$ & - & $<0.005$ & $<0.005$ & - & $<0.005$ & $<0.005$ & - & $<0.005$ & $<0.005$ & - & $<0.005$ & $<0.005$ & - \\
\hline Ti & 24 & $10.3^{b, e, f}$ & 11.5 & 6.8 & $0.88^{\mathrm{a}, \mathrm{c}}$ & 0.83 & 0.36 & $17^{\mathrm{b}, \mathrm{e}, \mathrm{f}}$ & 21 & 13 & 2.18 & 2.17 & 0.61 & $0.48^{\mathrm{a}, \mathrm{c}}$ & 0.48 & 0.27 & $0.078^{\mathrm{a}, \mathrm{c}}$ & 0.098 & 0.043 \\
\hline T1 & 15 & 0.012 & 0.015 & 0.010 & 0.00165 & 0.00164 & 0.00085 & 0.023 & 0.029 & 0.019 & $<0.0003$ & $<0.0003$ & - & $<0.0003$ & $<0.0003$ & - & $<0.0003$ & $<0.0003$ & - \\
\hline $\mathbf{U}$ & 19 & $0.130^{\mathrm{b}, \mathrm{d}, \mathrm{e}, \mathrm{f}}$ & 0.131 & 0.077 & $0.0106^{\mathrm{a}}$ & 0.0110 & 0.0030 & $0.058^{\mathrm{e}, \mathrm{f}}$ & 0.069 & 0.035 & $0.0047^{\mathrm{a}}$ & 0.0086 & 0.0092 & $<0.001^{a, c}$ & $<0.001$ & - & $<0.001^{\mathrm{a}, \mathrm{c}}$ & $<0.001$ & - \\
\hline $\mathbf{v}$ & 14 & 1.00 & 0.86 & 0.35 & $<0.03$ & $<0.03$ & - & 0.83 & 0.75 & 0.45 & 0.062 & 0.072 & 0.051 & $<0.03$ & $<0.03$ & - & $<0.03$ & $<0.03$ & - \\
\hline w & 11 & 0.078 & 0.066 & 0.021 & $<0.02$ & $<0.02$ & - & $<0.02$ & $<0.02$ & - & 0.09 & 0.11 & 0.10 & 0.0251 & 0.0251 & 0.0088 & $<0.02$ & $<0.02$ & - \\
\hline Zn & 24 & $178^{\mathrm{e}, \mathrm{f}}$ & 330 & 270 & $26^{c}$ & 46 & 47 & $766^{\mathrm{b}, \mathrm{d}, \mathrm{e}, \mathrm{f}}$ & 1070 & 870 & $39^{c}$ & 48 & 41 & $12.0^{\mathrm{a}, \mathrm{c}}$ & 12.0 & 2.9 & $2.3^{\mathrm{a}, \mathrm{c}}$ & 3.6 & 2.4 \\
\hline $\mathrm{Zr}$ & 14 & 0.76 & 0.61 & 0.44 & 0.108 & 0.123 & 0.048 & 1.14 & 1.36 & 0.68 & 0.18 & 0.20 & 0.16 & 0.24 & 0.24 & 0.25 & $<0.1$ & $<0.1$ & - \\
\hline
\end{tabular}

a Different superscript letters within rows are significantly different $(\mathrm{p}<0.05)$. $\mathrm{a}=$ PHA TV- $d$-ne.

b $\mathrm{b}=$ PHA TV- $d-\mathrm{CHCl} 3$.

c $\mathrm{c}=$ PHA TV-d-NaClO

$\mathrm{d}=$ PHA TV-a-ap.
$\mathrm{e}=$ PHA L-a-ap.

${ }^{\mathrm{f}} \mathrm{f}=$ PHA comm. 
regulation, PHA should not contain more than $100,5,2,1$, and $1 \mathrm{mg} \mathrm{kg}^{-1}$ of $\mathrm{Zn}, \mathrm{Cu}, \mathrm{Pb}, \mathrm{As}$, and $\mathrm{Cr}$, respectively (Table 2). By comparing these values with Table 1 , it can be seen that the contents of $\mathrm{Cr}, \mathrm{Cu}$, and $\mathrm{Pb}$ in PHA produced from municipal waste/ sludge exceeded these limits, while only the content of $\mathrm{Cu}$ exceeded the limit in PHA from fruit waste. Additionally, the content of $\mathrm{Cr}$ in commercial PHA exceeded the limit. Hence, in terms of heavy metals content, these samples did not comply with the regulations for plastics intended to come into direct contact with food, and the extraction techniques need to be further improved.

Inorganic species may be present as residues from the catalysts or additives used in the production of polyethene terephthalate (PET), the most favourable packaging material for drinking water (Bach et al., 2012). $\mathrm{Sb}_{2} \mathrm{O}_{3}$ is the preferred catalyst for the synthesis of PET due to its low cost and sufficient catalytic activity (Keresztes et al., 2009), and PET typically contains Sb levels in the range of 170-300 mg kg-1 (Nishioka et al., 2002; Keresztes et al., 2009; Westerhoff et al., 2008). The maximum average content of $\mathrm{Sb}$ $\left(0.131 \pm 0.085 \mathrm{mg} \mathrm{kg}^{-1}\right.$; Table 1$)$ of the studied PHA samples was approximately 1000 times lower than that in PET. Other metals, such as $\mathrm{Co}, \mathrm{Cr}$, Fe, and Mn, have also been found in PET bottles, with contents of $27,0.1,1.3$, and $0.3 \mathrm{mg} \mathrm{kg}^{-1}$, respectively (Westerhoff et al., 2008). In this case, the content of Co in all the PHA samples was at least 100 times lower, while that of Mn was lower than or similar to the values in literature for PHA L-a-ap and PHA comm.

\subsection{Migratable concentrations}

Extraction tests were conducted on all PHA samples to assess compliance/noncompliance with the European Directive migration limit (Table 2) and explore possible controls and variations in element migratability.

Table 3 summarises the results obtained for all analysed elements by the different migration tests in terms of concentration, and detailed data are provided in the Supplementary Material (Tables S4-S8). The migratable concentrations ranged from $<0.2 \mu \mathrm{g} \mathrm{kg}^{-1}$ for Be, Cs, La, Nb, Tl, and U to $>1000 \mathrm{mg} \mathrm{kg}^{-1}$ for Ca, K, $\mathrm{Mg}$, Na, and $\mathrm{P}$, and was highly variable, ranging from less than $1 \%$ to approximately $100 \%$. The results for each treatment are discussed in detail in the following sections.

Table 2

Migratable limits ( $\mathrm{mg} \mathrm{kg}^{-1}$ ) of elements in food and toys and as defined by the original and amended EC toy safety directives.

\begin{tabular}{|c|c|c|c|c|c|}
\hline \multirow[t]{2}{*}{ Element } & \multirow[t]{2}{*}{ CR (EU) No $10 / 2011^{\mathrm{a}}$} & \multirow[t]{2}{*}{$88 / 378 / \mathrm{EEC}^{\mathrm{b}}$} & \multicolumn{3}{|l|}{$2009 / 48 / \mathrm{EC}^{\mathrm{C}}$} \\
\hline & & & in dry, brittle, powder-like or pliable toy material & in liquid or sticky toy material & in scraped-off toy material \\
\hline Al & - & - & 5625 & 1406 & 70,000 \\
\hline As & $1^{\mathrm{e}}$ & 25 & 3.8 & 0.9 & 47 \\
\hline B & - & & 1200 & 300 & 15,000 \\
\hline Ba & 1 & 1000 & $4500(1500)$ & $1125(375)$ & $56,000(18,750)$ \\
\hline Be & - & - & - & - & - \\
\hline $\mathbf{B i}$ & - & - & - & - & - \\
\hline Ca & - & - & - & - & - \\
\hline Cd & & 75 & $1.9(1.3)$ & $0.5(0.3)$ & $23(17)$ \\
\hline Ce & - & - & - & - & - \\
\hline Co & 0.05 & - & 10.5 & 2.6 & 130 \\
\hline Cr & $1^{\mathrm{e}}$ & 60 & $\operatorname{Cr}(\mathrm{III})$ 37.5; $\mathrm{Cr}(\mathrm{VI}) 0.02$ & $\operatorname{Cr}(\mathrm{III})$ 9.4; $\operatorname{Cr}(\mathrm{VI}) 0.005$ & $\mathrm{Cr}(\mathrm{III})$ 460; $\mathrm{Cr}(\mathrm{VI}) 0.2$ \\
\hline Cs & - & - & - & - & - \\
\hline Cu & $5^{e}$ & - & 622.5 & 156 & 7700 \\
\hline $\mathbf{F e}$ & 48 & - & - & - & - \\
\hline Ga & - & - & - & - & - \\
\hline Hg & - & - & 7.5 & 1.9 & 94 \\
\hline $\mathbf{K}$ & - & - & - & - & - \\
\hline La & - & - & - & - & - \\
\hline $\mathbf{L i}$ & 0.6 & - & - & - & - \\
\hline Mg & - & - & - & - & - \\
\hline Mn & 0.6 & - & 1200 & 300 & 15,000 \\
\hline Mo & - & - & - & - & - \\
\hline Na & - & - & - & - & - \\
\hline Nb & - & - & - & - & - \\
\hline $\mathbf{N i}$ & - & - & 75 & 18.8 & 930 \\
\hline $\mathbf{P}$ & - & - & - & - & - \\
\hline $\mathbf{P b}$ & $2^{\mathrm{e}}$ & - & $13.5(2.0)$ & $3.4(0.5)$ & $160(23)$ \\
\hline $\mathbf{R b}$ & - & - & - & - & - \\
\hline Sb & 0.04 & 60 & 45 & 11.3 & 560 \\
\hline Se & - & - & 37.5 & 9.4 & 460 \\
\hline $\mathbf{S i}$ & - & - & - & - & - \\
\hline Sn & - & - & 15,000 & 3750 & 180,000 \\
\hline Sr & - & - & 4500 & 1125 & 56,000 \\
\hline Te & - & - & - & - & - \\
\hline Ti & - & - & - & - & - \\
\hline Tl & - & - & - & - & - \\
\hline $\mathbf{U}$ & - & - & - & - & - \\
\hline V & - & - & - & - & - \\
\hline W & - & - & - & - & - \\
\hline $\mathbf{Z n}$ & $25\left(100^{\mathrm{e}}\right)$ & - & 3750 & 938 & 46,000 \\
\hline $\mathrm{Zr}$ & - & - & - & - & - \\
\hline
\end{tabular}

${ }^{\text {a }}$ Commission Regulation (CR) (EU) No October 2011 (European Commission, 2011) on plastic materials and articles to come into contact with food establishes a set of specific requirements for PHA (which has been obtained through microbial fermentation by using Alcaligenes Eutrophus.

b The original European Council Directive 88/378/EEC (Council of the European Union, 1988) on toy safety stipulated migratable limits for eight hazardous elements.

c The amended Directive on toy safety (European Parliament, Council of the European Union, 2009) with revised values shown in parentheses. There is currently a proposal to reduce the concentration limits of $\mathrm{Pb}$ (Council of the European Union, 2017). 
Table 3

Summary of the migratable concentrations ${ }^{\mathrm{a}}$ ranges [minimum and maximum mean; $\mathrm{mg} \mathrm{kg}^{-1}$ ] of each element detected in the extracts of different PHA samples.

\begin{tabular}{|c|c|c|c|c|c|c|c|c|c|c|}
\hline \multirow[t]{2}{*}{ Element } & \multicolumn{2}{|c|}{$\mathrm{H}_{2} \mathrm{O}\left(10 \mathrm{~d} ; 20^{\circ} \mathrm{C}\right)$} & \multicolumn{2}{|c|}{$\mathrm{H}_{2} \mathrm{O}\left(2 \mathrm{~h} ; 70^{\circ} \mathrm{C}\right)$} & \multicolumn{2}{|c|}{$\mathrm{CH}_{3} \mathrm{COOH}\left(10 \mathrm{~d} ; 20^{\circ} \mathrm{C}\right)$} & \multicolumn{2}{|c|}{$\mathrm{CH}_{3} \mathrm{COOH}\left(2 \mathrm{~h} ; 70^{\circ} \mathrm{C}\right)$} & \multicolumn{2}{|c|}{$\mathrm{HCl}\left(2 \mathrm{~h} ; 37^{\circ} \mathrm{C}\right)$} \\
\hline & $\min$ & $\max$ & $\min$ & $\max$ & $\min$ & $\max$ & Min & $\max$ & $\min$ & $\max$ \\
\hline Al & $<0.2$ & 3.8 & 0.321 & 3.4 & $<0.04$ & 7.4 & 0.88 & 9 & $<0.1$ & 9 \\
\hline As & $<0.1$ & 0.16 & $<0.02$ & 0.107 & $<0.05$ & 0.210 & $<0.06$ & 0.46 & $<0.2$ & 0.87 \\
\hline B & $<0.2$ & 3.9 & 0.56 & 3.5 & 0.211 & 3.2 & 0.160 & 3.8 & 0.168 & 3.7 \\
\hline Ba & 0.39 & 1.01 & 0.401 & 1.4 & $<0.1$ & 18.8 & 0.364 & 18.7 & 0.285 & 25.6 \\
\hline Be & $<0.0003$ & 0.00044 & $<0.0002$ & 0.0024 & $<0.0002$ & 0.021 & $<0.0002$ & 0.0217 & $<0.0003$ & 0.037 \\
\hline $\mathbf{B i}$ & $<0.002$ & 0.0058 & $<0.001$ & 0.00733 & $<0.0007$ & 0.17 & 0.00074 & 0.064 & $<0.002$ & 0.19 \\
\hline Ca & 28 & 6190 & 100 & 7510 & 69 & 15,200 & 65 & 15,400 & 244 & 21,300 \\
\hline Cd & $<0.01$ & 0.08 & $<0.003$ & 0.09 & $<0.01$ & 0.27 & 0.00228 & 0.28 & $<0.005$ & 0.31 \\
\hline Ce & $<0.001$ & 0.0024 & $<0.001$ & 0.012 & 0.00061 & 0.22 & $<0.001$ & 0.2180 & 0.0014 & 0.42 \\
\hline Co & 0.0020 & 0.201 & 0.00236 & 0.244 & 0.0033 & 0.468 & 0.0058 & 0.48 & 0.0055 & 0.43 \\
\hline $\mathrm{Cr}$ & $<0.02$ & 0.15 & 0.0369 & 0.60 & $<0.02$ & 0.56 & 0.058 & 1.09 & $<0.3$ & 4.0 \\
\hline Cs & $<0.001$ & 0.0126 & $<0.0002$ & 0.0153 & $<0.0006$ & 0.0107 & $<0.001$ & 0.0230 & $<0.0002$ & 0.017 \\
\hline $\mathrm{Cu}$ & 0.26 & 21 & 0.28 & 35 & 0.26 & 56 & 0.22 & 65 & 0.24 & 67 \\
\hline $\mathbf{F e}$ & 0.21 & 54 & 0.25 & 3.9 & $<0.3$ & 156 & 1.29 & 171 & 0.7 & 520 \\
\hline Ga & 0.0081 & 0.027 & 0.00983 & 0.08 & 0.0107 & 0.47 & $<0.01$ & 0.34 & $<0.01$ & 0.43 \\
\hline Hg & $<0.001$ & 0.0028 & 0.0042 & 0.0118 & 0.00149 & 0.0239 & 0.0041 & 0.0272 & 0.0042 & 0.0396 \\
\hline $\mathbf{K}$ & 5.5 & 909 & 4.0 & 1245 & 7 & 896 & 12.4 & 1650 & 11.5 & 1400 \\
\hline La & $<0.0002$ & 0.0027 & $<0.001$ & 0.006 & 0.00077 & 0.17 & 0.0014 & 0.14 & 0.0012 & 0.35 \\
\hline $\mathbf{L i}$ & $<0.006$ & 0.104 & 0.0069 & 0.149 & 0.0034 & 0.118 & 0.00184 & 0.166 & $<0.01$ & 0.115 \\
\hline Mg & 14 & 2210 & 23 & 2860 & 21 & 4040 & 18 & 4110 & 26 & 6300 \\
\hline Mn & $<0.1$ & 21.7 & $<0.1$ & 17 & $<0.1$ & 102 & 0.16 & 103 & 0.219 & 168 \\
\hline Mo & $<0.01$ & 0.146 & $<0.02$ & 0.32 & $<0.003$ & 0.027 & 0.0058 & 0.076 & 0.0095 & 0.0581 \\
\hline $\mathrm{Na}$ & 100 & 22,700 & 195 & 37,800 & 93 & 26,800 & 156 & 35,000 & 105 & 22,800 \\
\hline $\mathbf{N b}$ & $<0.0002$ & 0.00113 & $<0.0003$ & 0.00059 & 0.000145 & 0.0064 & $<0.0004$ & 0.00606 & $<0.0003$ & 0.0074 \\
\hline $\mathrm{Ni}$ & 0.10 & 3.2 & 0.11 & 3.8 & $<0.1$ & 11.5 & $<0.1$ & 11.3 & $<0.1$ & 12.5 \\
\hline $\mathbf{P}$ & $<2$ & 1280 & 6.0 & 778 & 10.9 & 3020 & 8.7 & 1700 & 5.0 & 1840 \\
\hline $\mathbf{P b}$ & 0.0180 & 19 & $<0.01$ & 18 & 0.036 & 12.5 & 0.064 & 11.4 & 0.040 & 35 \\
\hline $\mathbf{R b}$ & 0.0053 & 0.62 & 0.0020 & 0.83 & 0.0073 & 0.59 & 0.012 & 1.06 & 0.0071 & 0.87 \\
\hline Sb & $<0.04$ & $<0.04$ & $<0.04$ & 0.177 & $<0.04$ & $<0.04$ & $<0.04$ & 0.062 & $<0.04$ & 0.083 \\
\hline Se & $<0.2$ & 0.308 & $<0.1$ & 0.35 & $<0.04$ & 0.127 & $<0.08$ & 0.18 & $<0.4$ & 0.55 \\
\hline Si & 5.0 & 48 & $<6$ & 97 & $<30$ & 102 & 26.7 & 112 & $<6$ & 440 \\
\hline Sn & 0.0012 & 0.012 & 0.004 & 0.016 & 0.00105 & 0.12 & 0.00346 & 0.110 & $<0.001$ & 0.26 \\
\hline $\mathbf{S r}$ & 0.17 & 31 & 0.33 & 25 & 0.19 & 62 & 0.17 & 62 & 0.30 & 72.0 \\
\hline Te & $<0.01$ & $<0.01$ & $<0.003$ & 0.0086 & $<0.01$ & 0.0158 & $<0.01$ & $<0.01$ & $<0.03$ & 0.038 \\
\hline Ti & $<0.1$ & 13 & 0.0517 & 13 & $<0.03$ & 8.3 & 0.0353 & 13.6 & $<1$ & 28 \\
\hline Tl & $<0.0003$ & 0.0032 & $<0.0002$ & 0.0080 & $<0.0003$ & 0.0156 & $<0.0006$ & 0.0135 & $<0.004$ & 0.010 \\
\hline $\mathbf{U}$ & $<0.0002$ & 0.0011 & $<0.0003$ & 0.0045 & $<0.0003$ & 0.019 & $<0.0003$ & 0.039 & $<0.0003$ & 0.038 \\
\hline $\mathbf{V}$ & $<0.03$ & 0.138 & $<0.04$ & 0.55 & $<0.02$ & 0.25 & $<0.04$ & 0.62 & $<1$ & $<1$ \\
\hline $\mathbf{W}$ & $<0.001$ & 0.012 & 0.0056 & 0.08 & $<0.001$ & 0.011 & $<0.002$ & 0.017 & $<0.001$ & 0.0103 \\
\hline $\mathrm{Zn}$ & 0.43 & 19.5 & 0.471 & 11.6 & 1.2 & 607 & 1.01 & 620 & 1.4 & 715 \\
\hline $\mathrm{Zr}$ & 0.00040 & 0.018 & $<0.001$ & 0.019 & 0.00119 & 0.09 & 0.00040 & 0.0901 & 0.0014 & 0.13 \\
\hline
\end{tabular}

a Note that numbers in bold denote non-compliance according to the Commission Regulation (EU) No October 2011 (European Commission, 2011 ) for migration test with

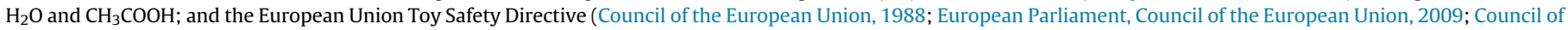
the European Union, 2017) for migration test with $\mathrm{HCl}$. Contact time in days (d) or hours (h) at contact temperature in ${ }^{\circ} \mathrm{C}$.

\subsubsection{Element migratability in water}

The elemental analysis results for the $\mathrm{H}_{2} \mathrm{O}$ experiment are presented in Tables 3, S4, and S5. The concentrations of many of the minerals commonly found in $\mathrm{H}_{2} \mathrm{O}$, including $\mathrm{Ca}, \mathrm{K}, \mathrm{Mg}, \mathrm{Na}$, and $\mathrm{P}$, were elevated, and the levels of many trace elements were lower. Heating can increase the migration speed and concentrations of migrated elements than the storage of solutions at room temperature $\left(20^{\circ} \mathrm{C}\right)$. The concentrations of $\mathrm{Cu}, \mathrm{Mn}$, and $\mathrm{Sb}$ in PHA TV- $d$-ne and Sb in PHA TV-a-ap after heating to $70{ }^{\circ} \mathrm{C}$ for $2 \mathrm{~h}$ were higher than those achieved 10 days at $20^{\circ} \mathrm{C}$. Small differences were detected for the other elements in all PHA samples.

The migration test for materials and articles intended for food contact was conducted using the time and temperature specified in Commission Regulation (EU) No October 2011 (European Commission, 2011). We conducted the following overall migration tests: 1) test for 10 days at $20^{\circ} \mathrm{C}$, covering any contact with food under frozen and refrigerated conditions; and 2) tests for $2 \mathrm{~h}$ at $70^{\circ} \mathrm{C}$, covering all other contact conditions, including heating up to $70^{\circ} \mathrm{C}$ for up to $2 \mathrm{~h}$, or up to $100^{\circ} \mathrm{C}$ for up to $15 \mathrm{~min}$, which are not followed by long-term storage at room or refrigerated temperatures. The contents of $\mathrm{Ba}, \mathrm{Co}$, and $\mathrm{Cu}$ in PHA TV- $d$-ne; $\mathrm{Mn}$ in PHA TV- $d$-ne, PHA TV- $d-\mathrm{CHCl}_{3}$, and PHA TV- $d-\mathrm{NaClO}$; and $\mathrm{Pb}$ in
PHA TV- $d-\mathrm{NaClO}$ exceeded the migration limits of Commission Regulation (EU) No October 2011 for both tests. The contents of Ba in PHA TV- $d-\mathrm{CHCl}_{3}$ and Fe in PHA TV- $d$-ne exceeded the limits for test 1), and those of $\mathrm{Ba}$ in PHA TV- $d-\mathrm{NaClO}$ and $\mathrm{Sb}$ in all PHA samples, excluding PHA TV- $d-\mathrm{CHCl}_{3}$ and PHA comm, exceeded the limits for test 2). The concentrations of all the selected elements in PHA comm were below the migration limits, thus, these PHA samples are food (water)-contact safe under frozen and refrigerated conditions, at $70{ }^{\circ} \mathrm{C}$ for $2 \mathrm{~h}$, or at $100{ }^{\circ} \mathrm{C}$ for up to $15 \mathrm{~min}$.

The lower levels of elements observed in polymeric materials than $\mathrm{Sb}$ explain the lack of studies conducted on elemental migration into bottled water (Bach et al., 2012). The specific migration limit for $\mathrm{Sb}$ is $0.04 \mathrm{mg} \mathrm{kg} \mathrm{kg}^{-1}$ (European Commission, 2011). Consistent with our results, temperature significantly affects the release of Sb (Bach et al., 2012; Cheng et al., 2010; Keresztes et al., 2009; Westerhoff et al., 2008). There were no significant traces of inorganic elements other than Sb in PET-bottled water subjected to different conditions (Cheng et al., 2010; Reimann et al., 2010), and more metals (Al, Ce, Pb, and Zr) can leach from glass into water than PET bottles (Reimann et al., 2010). 


\subsubsection{Element migratability in $\mathrm{CH}_{3} \mathrm{COOH}$}

Tables 3, S6, and S7 show the results of testing PHA samples with $\mathrm{CH}_{3} \mathrm{COOH}$, i.e., food simulant B listed in Commission Regulation (EU) No. October 2011 (European Commission, 2011). Food simulants must be used to test migration from materials and articles not yet in contact with food. Food simulant B is used for foods with hydrophilic characteristics, can extract hydrophilic substances, and have a pH below 4.5 (beverages, such as clear fruit or vegetable juices of normal strength or concentrated, fruit nectars, lemonades; and milk products, such as fermented milk including yoghurt, buttermilk and similar products, and processed and preserved cheese) The data show that the concentrations of elements such as $\mathrm{Ba}, \mathrm{Co}, \mathrm{Cu}, \mathrm{Fe}, \mathrm{Mn}$, and $\mathrm{Zn}$ increased under acidic conditions (Tables 3, S6, and S7). The maximum levels of the analysed elements in $\mathrm{CH}_{3} \mathrm{COOH}$ increased by more than double the concentration obtained in $\mathrm{H}_{2} \mathrm{O}$ (Table 3). The levels of elements released from PHA L-a-ap and PHA comm were below the migration limits; thus, these materials are safe for contact with food under frozen and refrigerated conditions, while PHA comm is safe for contact with food at $70{ }^{\circ} \mathrm{C}$ for $2 \mathrm{~h}$, or at $100{ }^{\circ} \mathrm{C}$ for up to $15 \mathrm{~min}$.

In contrast with our results, for all analysed elements ( $\mathrm{Ag}, \mathrm{Al}, \mathrm{As}$, $\mathrm{Ba}, \mathrm{Cd}, \mathrm{Co}, \mathrm{Cr}, \mathrm{Cu}, \mathrm{Mn}, \mathrm{Mo}, \mathrm{Ni}, \mathrm{Pb}, \mathrm{Se}, \mathrm{Tl}$, and $\mathrm{V}$ ), excluding $\mathrm{Sb}$, in all PET bottle samples, Cheng et al. (2010) detected no significant leaching due to low $\mathrm{pH}$, and the levels of metals were well below the specific migration limit listed in Commission Regulation (EU) No October 2011 (European Commission, 2011). Keresztes et al. (2009) also demonstrated that the Sb dissolution rate into water is higher into sparkling water than that into still water due to the lower $\mathrm{pH}$ of carbonated water.

\subsubsection{Element migratability in $\mathrm{HCl}$}

The original European Council Directive 88/378/EEC (Council of the European Union, 1988) on toy safety stipulated migratable limits for some hazardous elements based on the ingestion of a small amount of material and defined by $2 \mathrm{~h}$ of extraction under simulated gastric conditions (dilute $\mathrm{HCl}$ at $37{ }^{\circ} \mathrm{C}$ ) according to European standard EN 71-3, as listed in Table 2 (British Standards Institution (BSI), 1994; Turner, 2018). An amended directive (European Parliament, Council of the European Union, 2009) provided revised limits on migration in dilute $\mathrm{HCl}$ that depended on the matrix being tested (dry, brittle, powder-like, or pliable toy materials; liquid or sticky toy materials; and scraped-off toy materials), as well as limits for additional elements and different oxidation states of $\mathrm{Cr}$ (Table 2). Furthermore, there is currently a proposal to reduce the concentration limits of $\mathrm{Pb}$ (Council of the European Union, 2017). The results of this study (Tables 3 and S8) reveal low concentrations of the elements listed by the original Toy Safety Directive (European Council Directive 88/378/EEC). Instead, the extracted concentrations of $\mathrm{Cd}$ in PHA TV- $d-\mathrm{NaClO}$ and $\mathrm{Pb}$ in all PHA samples excluding PHA L-a-ap and PHA comm exceeded the current or proposed European migratable limits.

The contents of $\mathrm{Cd}$ and $\mathrm{Pb}$ in second-hand plastic toys also exceeded their migration limits stipulated by the current EU Toy Safety Directive, with the release of Cd from yellow and red Lego bricks exceeding the limit by one order of magnitude (Turner, 2018). Cd and $\mathrm{Pb}$ were used as stabilisers in polyvinyl chloride (PVC) or, in association with other elements ( $\mathrm{Cr}, \mathrm{Mo}$, and $\mathrm{S}$ ) as coloured pigments (Turner, 2018).

\subsubsection{Bioaccessibilities of elements}

Exposure to elemental concentrations and their health hazards are related to their migratable levels rather than their total contents. The percentage migration relative to the total elemental content can be a measure of the bioaccessibility. The results shown in Fig. 1 and S1-S4 indicate wide variations in the bioaccessibility of the toxic elements listed in Table 2. Sb and Se were not considered because all data were $<$ LOQs. The standard deviation of the mean bioaccessibility percentage values in each PHA was very high as the elemental composition of each PHA sample collected at different operation times from the pilot plant (batch) was highly variable. Therefore, we reported all the results for each batch of the different types of PHA. Generally, the migration of elements is higher in acidic solutions and with heating (Fig. 1 and S1-S4). For all considered conditions, the bioaccessibility percentages of $\mathrm{Al}, \mathrm{Cr}$, and Fe were lower than 60\% for all types of PHA, and that of Sn was below $40 \%$ (Fig. S1). As, $\mathrm{Cd}$, and $\mathrm{Hg}$ appeared to be more bioaccessible in PHA TV- $d$-ne; PHA TV- $d$-ne and PHA TV-NaClO; and PHA TV-NaClO and PHA TV-a-ap (Fig. 1), respectively.

\section{Conclusions}

In the context of the European Circular Economy strategy, an analytical method for determining the presence and migration of 41 elements, including alkaline metals, alkaline earth metals, heavy metals and metalloids, in PHA biopolymers was optimised. The obtained LODs were suitable for the identifying element concentrations well below the limits set for plastic materials by European regulations.

PHA samples produced from different origins and with different process steps were analysed. The elemental content of PHA was generally low, ranging from ppb to a few ppm, except for alkaline and alkaline earth metals (which are of little environmental concern). The feedstock type affected the contaminant levels, with the PHA from fruit waste having a lower element content than PHA obtained from the mixture of the organic fraction of municipal waste and sludge from wastewater treatment. The crop-derived commercial PHA was found to have lower concentrations of heavy metals than the waste-based PHA samples. The PHA stabilisation and extraction process also affected the contents of contaminants, where acid stabilisation and extraction with aqueous extractants resulted in lower heavy metal contents than thermal stabilisation and extraction with either hypochlorite or chloroform.

Although there is currently no specific regulation, the PHA samples were compared to the regulations and guidelines for similar materials and/or applications. The total content of the analysed elements for all tested PHA types complied with the current regulations and guidelines, such as the limits for $\mathrm{Cd}$ in plastic materials based on $\mathrm{REACH}$ regulation, including toys. According to Commission Regulation (EU) No 10/2011, PHA TV-a-ap and PHA L-a-ap are food (water)-contact safe under frozen and refrigerated conditions and PHA comm in all tested conditions; PHA L-a-ap and PHA are safe for contact with food under frozen and refrigerated conditions, and PHA comm is safe for contact with food at $70^{\circ} \mathrm{C}$ for $2 \mathrm{~h}$, or at $100^{\circ} \mathrm{C}$ for up to $15 \mathrm{~min}$. The levels of elements released from PHA L-a-ap and PHA comm were below the migration limits as stipulated by the current and proposed EU Toy Safety Directive.

\section{CRediT authorship contribution statement}

Maria Luisa Astolfi: Conceptualization, Data curation, Formal analysis, Investigation, Supervision, Validation, Visualization, Writing - original draft, Writing - review \& editing. Elisabetta Marconi: Investigation, Visualization. Laura Lorini: Data curation, Resources. Francesco Valentino: Resources, Writing - review \& editing. Fernando Silva: Resources. Bruno Sommer Ferreira: Resources. Silvia Canepari: Resources, Writing - review \& editing. Mauro Majone: Conceptualization, Funding acquisition, Project administration, Resources, Supervision, Writing - review \& editing. 


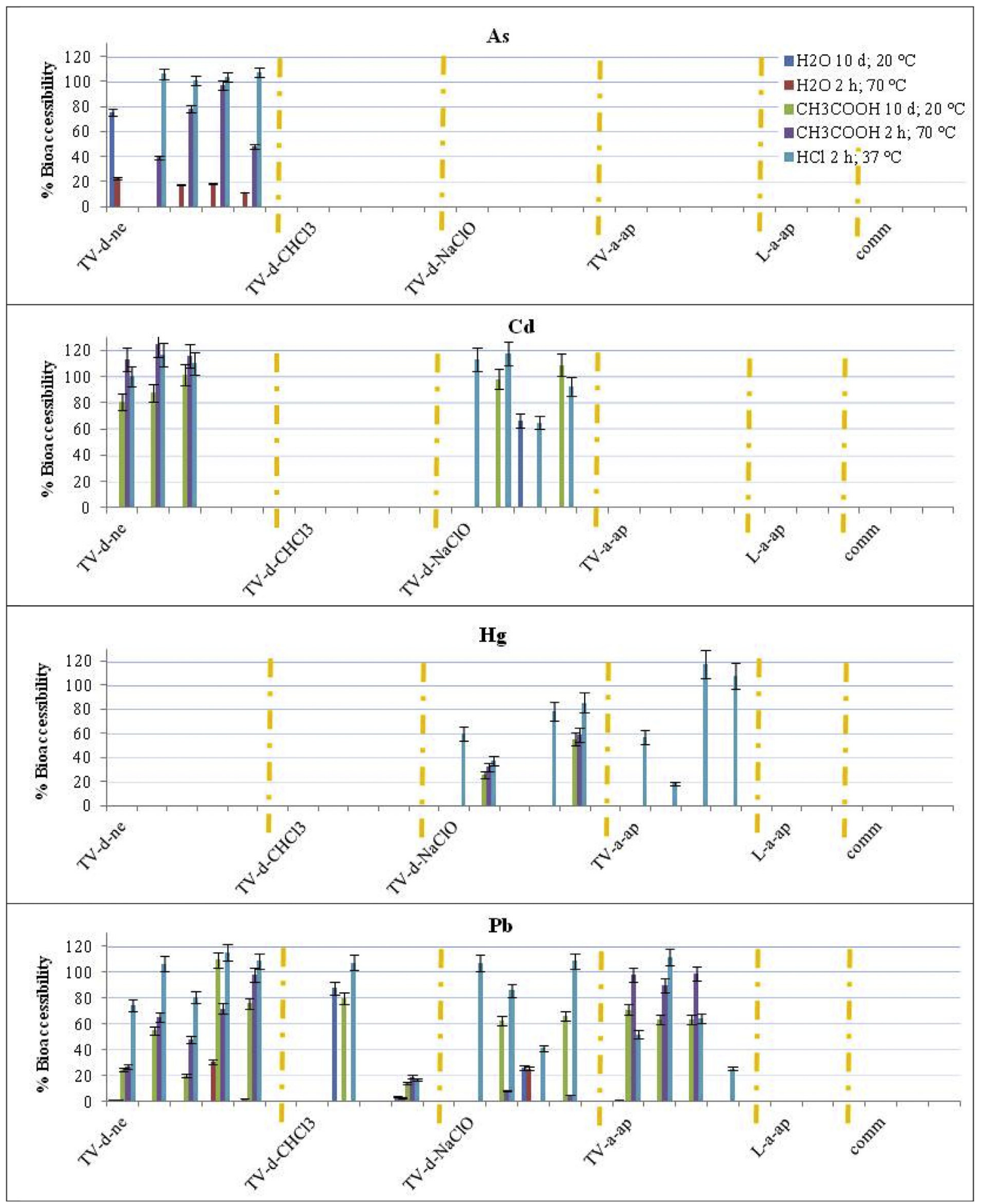

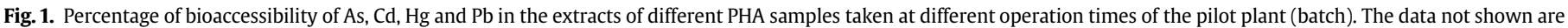
lower than the quantification limits.

\section{Declaration of competing interest}

The authors declare that they have no known competing financial interests or personal relationships that could have appeared to influence the work reported in this paper.

\section{Acknowledgments}

This work was supported by the "REsources from URban BIowaSte" - RES URBIS (GA 7303499) project in the European Horizon 2020 (Call CIRC-05-2016) program. 


\section{Appendix A. Supplementary data}

Supplementary data to this article can be found online at https://doi.org/10.1016/j.chemosphere.2020.127472.

\section{References}

Alina, M., Azrina, A., Mohd Yunus, A.S., Mohd Zakiuddin, S., Mohd Izuan Effendi, H. Muhammad Rizal, R., 2012. Heavy metals (mercury, arsenic, cadmium, plumbum) in selected marine fish and shellfish along the Straits of Malacca. Int. Food Res. J. 19, 135-140.

Altaş, L., 2009. Inhibitory effect of heavy metals on methane-producing anaerobic granular sludge. J. Hazard Mater. 162, 1551-1556. https://doi.org/10.1016/ j.jhazmat.2008.06.048.

Astolfi, M.L., Protano, C., Marconi, E., Massimi, L., Brunori, M., Piamonti, D., Migliara, G., Vitali, M., Canepari, S., 2020a. A new treatment of human hair for elemental determination by inductively coupled mass spectrometry. Anal. Methods 12, 1906-1918. https://doi.org/10.1039/C9AY01871A.

Astolfi, M.L., Marconi, E., Protano, C., Canepari, S., 2020b. Comparative elemental analysis of dairy milk and plant-based milk alternatives. Food Contr. 116, 1-11. https://doi.org/10.1016/j.foodcont.2020.107327, 107327.

Astolfi, M.L., Protano, C., Schiavi, E., Marconi, E., Capobianco, D., Massimi, L., Ristorini, M., Baldassarre, M.E., Laforgia, N., Vitali, M., Canepari, S., Mastromarino, P., 2019a. A prophylactic multi-strain probiotic treatment to reduce the absorption of toxic elements: in-vitro study and biomonitoring of breast milk and infant stools. Environ. Int. 130, 104818. https://doi.org/10.1016/ j.envint.2019.05.012.

Astolfi, M.L., Protano, C., Marconi, E., Piamonti, D., Massimi, L., Brunori, M., Vitali, M., Canepari, S., 2019b. Simple and rapid method for the determination of mercury in human hair by cold vapour generation atomic fluorescence spectrometry. Microchem. J. 150, 104186. https://doi.org/10.1016/j.microc.2019.104186.

Astolfi, M.L., Di Filippo, P., Gentili, A., Canepari, S., 2017. Semiautomatic sequential extraction of polycyclic aromatic hydrocarbons and elemental bio-accessible fraction by accelerated solvent extraction on a single particulate matter sample. Talanta 174, 838-844. https://doi.org/10.1016/j.talanta.2017.06.072.

Astolfi, M.L., Canepari, S., Catrambone, M., Perrino, C., Pietrodangelo, A., 2006. Improved characterisation of inorganic components in airborne particulate matter. Environ. Chem. Lett. 3, 186-191. https://doi.org/10.1007/S10311-0050029-7.

Bach, C., Dauchy, X., Chagnon, M.-C., Etienne, S., 2012. Chemical compounds and toxicological assessments of drinking water stored in polyethylene terephthalate (PET) bottles: a source of controversy reviewed. Water Res. 46, 571-583. https://10.1016/j.watres.2011.11.062.

Bardos, P., 2004. Composting of Mechanically Segregated Fractions of Municipal Solid Waste - A Review. Falfield. Sita Environmental Trust, Bristol.

British Standards Institution (BSI), 1994. Safety of toys - part 3: migration of certain elements. British Standard BS EN 71-3. London.

Canepari, S., Castellano, P., Astolfi, M.L., Materazzi, S., Ferrante, R., Fiorini, D., Curini, R., 2018. Release of particles, organic compounds, and metals from crumb rubber used in synthetic turf under chemical and physical stress. Environ. Sci. Pollut. Res. 25, 1448-1459. https://doi.org/10.1007/s11356-017-0377-4.

Cheng, X., Shi, H., Adams, C.D., Ma, Y., 2010. Assessment of metal contaminations leaching out from recycling plastic bottles upon treatments. Environ. Sci. Pollut. Res. 17 (7), 1323-1330. https://doi.org/10.1007/s11356-010-0312-4.

Chowdhury, U.K., Biswas, B.K., Chowdhury, T.R., Samanta, G., Mandal, B.K., Basu, G.C., Chanda, C.R., Lodh, D., Saha, C., Mukherjee, S.K., Roy, S., Kabir, S., Quamruzzaman, Q., Chakraborti, D., 2000. Groundwater arsenic contamination in Bangladesh and West Bengal, India. Environ. Health Perspect. 108, 393-397. https://doi.org/10.1289/ehp.00108393.

Council of the European Union, 2017. Council Directive (EU) 2017/738 of 27 March 2017 amending, for the purpose of adapting to technical progress, Annex II to Directive 2009/48/EC of the European Parliament and of the Council on the safety of toys, as regards lead (Text with EEA relevance). Off. J. Eur. Union L. 110, 6-8. https://eur-lex.europa.eu/legal-content/EN/TXT/PDF/?uri=CELEX: 32017L0738\&from=EN. (Accessed 17 March 2020).

Council of the European Union, 1988. Council Directive of 3 May 1988 on the approximation of the laws of the Member States concerning the safety of toys (88/378/EEC). Off. J. Eur. Union L. 187, 1-13. https://eur-lex.europa.eu/legalcontent/EN/TXT/PDF/?uri=CELEX:31988L0378\&from=en. (Accessed 17 March 2020)

European Commission, 2015. Communication from the Commission to the European Parliament, the Council, the European Economic and Social Committee and the Committee of the Regions: Closing the Loop - an EU Action Plan for the Circular Economy, Communication 0614. European Commission, Brussels.

European Commission, 2011. Commission Regulation (EU) No 10/2011 of 14 January 2011 on plastic materials and articles intended to come into contact with food. Off. J. Eur. Union. L12, 1-89.

European Parliament, Council of the European Union, 2009. Directive 2009/48/EC on the safety of toys. Off. J. Eur. Union. L170, 1-37. https://doi.org/10.2873/ 141709.

European Parliament, Council of the European Union, 2006. Commission regulation (EU) No 1907/2006 of 18 december 2006 concerning the registration, evaluation, authorisation and restriction of chemicals (REACH), off. J. Eur. Union L396,
$1-849$.

European Parliament, Council of the European Union, 1994. Directive 94/62/EC on packaging and packaging waste. Off. J. Eur. Union. L365, 10-23. https://doi.org 10.1038/sj.bdj.4811054.

He, Z.L., Yang, X.E., Stoffella, P.J., 2005. Trace elements in agroecosystems and impacts on the environment. J. Trace Elem. Med. Biol. 19, 125-140. https://doi.org/ 10.1016/j.jtemb.2005.02.010.

Henson, M.C., Chedrese, P.J., 2004. Endocrine disruption by cadmium, a common environmental toxicant with paradoxical effects on reproduction. Exp. Biol. Med. 229, 383-392. https://doi.org/10.1177/153537020422900506.

Italian Regulation, 1998. Ministerial Decree n. 186 of 1998. Regolamento recante modifiche al decreto ministeriale 5 febbraio 1998 «Individuazione dei rifiut non pericolosi sottoposti alle procedure semplificate di recupero, ai sensi degli articoli 31 e 33 del decreto legislativo 5 febbraio 1997.

Järup, L., 2003. Hazards of heavy metal contamination. Br. Med. Bull. 68, 167-182. https://doi.org/10.1093/bmb/ldg032.

Keresztes, S., Tatar, E., Mihucz, V.G., Virága, I., Majdikd, C., Záray, G., 2009. Leaching of antimony from polyethylene terephthalate (PET) bottles into mineral water Sci. Total Environ. 407, 4731-4735. https://doi.org/10.1016/ j.scitotenv.2009.04.025.

Khiewwijit, R., Keesman, K.J., Rijnaarts, H., Temmink, H., 2015. Volatile fatty acids production from sewage organic matter by combined bioflocculation and anaerobic fermentation. Bioresour. Technol. 193, 150-155. https://doi.org/ 10.1016/j.biortech.2015.06.103.

Kourmentza, C., Plácido, J., Venetsaneas, N., Burniol-Figols, A., Varrone, C., Gavala, H.N., Reis, M.A., 2017. Recent advances and challenges towards sustainable polyhydroxyalkanoate (PHA) production. Bioengineering 4,55 . https:// doi.org/10.3390/bioengineering4020055.

Manigrasso, M., Protano, C., Astolfi, M.L., Massimi, L., Avino, P., Vitali, M., Canepari, S., 2019. Evidences of copper nanoparticle exposure in indoor environments: long-term assessment, high-resolution field emission scanning electron microscopy evaluation, in silico respiratory dosimetry study and possible health implications. Sci. Total Environ. 653, 1192-1203. https://doi.org/ 10.1016/j.scitotenv.2018.11.044.

Marconi, E., Canepari, S., Astolfi, M.L., Perrino, C., 2011. Determination of Sb (III), Sb (V) and identification of Sb-containing nanoparticles in airborne particulate matter. Procedia Environ. Sci. 4, 209-217. https://doi.org/10.1016/ j.proenv.2011.03.025.

Martin, S., Griswold, W., 2009. Human health effects of heavy metals. Environmental Science and Technology briefs for citizens 15, 1-6.

Nishioka, K., Hirahara, A., Iwamoto, E., 2002. Determination of antimony in polyethylene terephthalate bottles by graphite furnace atomic absorption spectrometry using microwave sample preparation. Bulletin of the Institute of Life Science, Hiroshima Prefectural Women's University 8, 35-42.

Reimann, C., Birke, M., Filzmoser, P., 2010. Bottled drinking water: water contamination from bottle materials (glass, hard PET, soft PET), the influence of colour and acidification. Appl. Geochem. 25 (7), 1030-1046. https://doi.org/10.1016/ j.apgeochem.2010.04.009.

Smith, A.H., Lingas, E.O., Rahman, M., 2000. Contamination of drinking-water by arsenic in Bangladesh: a public health emergency. Bull. World Health Organ. 78 1093-1103. https://doi.org/10.1590/S0042-96862000000900005.

Tsang, Y.F., Kumar, V., Samadar, P., Yang, Y., Lee, J., Ok, Y.S., Song, H., Kime, K.-H., Kwon, E.E., Jeon, Y.J., 2019. Production of bioplastic through food waste valorization. Environ. Int. 127, 625-644. https://doi.org/10.1016 j.envint.2019.03.076.

Turner, A., 2018. Concentrations and migratabilities of hazardous elements in second-hand children's plastic toys. Environ. Sci. Technol. 2018 52, 3110-3116. https://doi.org/10.1021/acs.est.7b04685.

Valentino, F., Moretto, G., Gottardo, M., Pavan, P., Bolzonella, D., Majone, M., 2019a Novel routes for urban bio-waste management: a combined acidic fermentation and anaerobic digestion process for platform chemicals and biogas production. J. Clean. Prod. 220, 368-375. https://doi.org/10.1016/j.jclepro.2019.02.102.

Valentino, F., Moretto, G., Lorini, L., Bolzonella, D., Pavan, P., Majone, M., 2019b. Pilot-Scale polyhydroxyalkanoate production from combined treatment of organic fraction of municipal solid waste and sewage sludge. Ind. Eng. Chem. Res. 58 (27), 12149-12158. https://doi.org/10.1021/acs.iecr.9b01831.

Valentino, F., Gottardo, M., Micolucci, F., Pavan, P., Bolzonella, D., Rossetti, S., Majone, M., 2018. Organic fraction of municipal solid waste recovery by conversion into added-value polyhydroxyalkanoates and biogas. ACS Sustain Chem. Eng. 6 (12), 16375-16385. https://doi.org/10.1021/ acssuschemeng.8b03454.

Valentino, F., Morgan-Sagastume, F., Campanari, S., Villano, M., Werker, A Majone, M., 2017. Carbon recovery from wastewater through bioconversion into biodegradable polymers. N. Biotech. 37, 9-23. https://doi.org/10.1016/ j.nbt.2016.05.007.

Vitali, M., Antonucci, A., Owczarek, M., Guidotti, M., Astolfi, M.L., Manigrasso, M. Avino, P., Bhattacharya, B., Protano, C., 2019. Air quality assessment in different environmental scenarios by the determination of heavy metals, PAHs, PCDDs, PCDFs, PCBs and PBDEs in native lichen Xanthoria Parietina. Environ. Pollut. 254, 113013. https://doi.org/10.1016/j.envpol.2019.113013.

Westerhoff, P., Prapaipong, P., Shock, E., Hillaireau, A., 2008. Antimony leaching from polyethylene terephthalate (PET) plastic used for bottled drinking water Water Res. 42 (3), 551-556. https://doi.org/10.1016/j.watres.2007.07.048. 